\title{
PERANCANGAN SISTEM INFORMASI PENILAIAN SISWA TAMAN KANAK-KANAK PADA RA.DARUSSALAM TANGERANG BERBASIS WEB
}

\author{
Suwarto $^{1}$, Ita Erliyani ${ }^{2}$, Mita Triana Putri ${ }^{* 3}$ \\ ${ }^{1,2,3}$ Program Studi Sistem Informasi Fakultas Sains dan Teknologi Universitas Raharja \\ Email: ${ }^{1}$ suwarto@ raharja.info, ${ }^{2}$ ita.erliyani@ raharja.info, ${ }^{* 3} \underline{\text { mita@ raharja.info }}$
}

\begin{abstract}
Abstrak
Dengan perkembangan teknologi yang semakin berkembang, maka saran dan prasarana dalam dunia pendidikan harus dikembangkan. Pendidikan adalah proses pembelajaran pengetahuan, keterampilan, melalui pengajaran, pelatihan, penelitian. Salah satu kegiatan pengajaran yaitu penilaian siswa. Nilai adalah hasil kegiatan belajar selama proses belajar. Sistem penilaian siswa pada RA.DARUSSALAM Tangerang masih sangat manual. Permasalahan yang saat ini berjalan adalah terdapat 35 siswa dan masing-masing siswa memiliki nilai yang berbeda-beda. Selama ini nilai siswa masih manual yang dicatat dibuku raport, sehingga membutuhkan waktu yang sangat lama dalam proses pengerjaannya.Adapun tujuan dari penelitian ini adalah untuk mempermudah penilaian raport dengan menggunakan sistem berbasis web pada RA.DARUSSALAM. Dengan adanya sistem pengolahan nilai raport secara terkomputerisasi diharapkan dapat efektif dan efesien. Hal ini guna mempermudah guru kelas dalam penginputan nilai dalam memperoleh nilai dari tiap siswa-siswi yang sudah mengikuti proses kegiatan pembelajaran.
\end{abstract}

Kata Kunci - Sistem, Pengolahan nilai dan Raport

\begin{abstract}
The development of technology that is increasingly developing, eating advice and infrastructure in the world of education must be developed. education is a resource to develop the potential of Human Resources (HR) through teaching activities. one of the teaching activities is student assessment. Value is the result of learning activities during prosea learning. Student assessment system in RA.Darussalan Tangerang is not yet fully computerized. the problem that currently runs is in one school there are 35 students and each student has different values. all this time the student's grades are still manually recorded in the report card, so it takes a very long time in the process. As for the purpose of this study is to facilitate the assessment of report cards using a web-based system in RA.DARUSSALAM. with the existence of computerized report card value processing systems it is expected to be effective and efficient. this is to facilitate the classroom teacher in inputting values in obtaining values from each student who has followed the learning process.
\end{abstract}

Keywords — system, value processing, report cards

\section{PENDAHULUAN}

Perkembangan ilmu pengetahuan dan teknologi di Indonesia saat ini sangatlah pesat, masyarakat memanfaatkan perkembangan tersebut sebagai suatu sarana pengolahan data informasi secara cepat, tepat, akurat, dan sistematis. Internet sudah banyak diaplikasikan dalam 
berbagai bidang kehidupan diantaranya dalam bidang hiburan, pendidikan, dan perdagangan. Salah satu yang berpengaruh adalah dalam bidang pendidikan.

Sekolah adalah salah satu contoh bidang pendidikan yang terkena dampak dari kemajuan teknologi komputer. Salah satu bagian terpenting dari suatu sekolah adalah siswa dan nilai siswa. Dalam satu sekolah terdapat puluhan siswa dan masing-masing mempunyai nilai yang berbeda-beda. Tidak jarang penyimpanan nilai siswa dicatat dan disimpan disebuah rak/laci lemari, sehingga membutuhkan waktu yang lama dalam pengerjaannya. Sementara hasil dari pengolahan data nilai siswa hanya bisa dilihat oleh orang tua siswa pada buku raport. Hal ini menyebabkan para orangtua tidak bisa setiap saat mengecek nilai putralputrinya di sekolah.

\section{PERMASALAHAN}

Berdasarkan latar belakang dan berdasarkan pengamatan yang dilakukan antara lain, adanya permasalahan Sistem penilaian raport pada RA. DARUSSALAM Tangerang masih manual, yang dilakukan saat ini hanyalah guru menulis penilaian siswa tersebut langsung pada buku raport, terkadang guru menulisnya dengan pensil dahulu agar tidak mengakibatkan dalam berkata-kata diraport tersebut dan menghindari penggunaan tipe-x agar tetap terlihat rapi sehingga memerlukan proses pengerjaan yang lama, terkadang ada juga kecerobohan yang dilakukan guru seperti raport basah terkena air dan ada juga kotor terkena makanan, ada juga guru yang lupa menyimpan raport siswa sehingga mengakibatkan raport hilang. Setelah ditulis, raport disimpan dan dibagikan kepada setiap siswa pada waktu penyerahan raport berlangsung. Dalam jangka waktu yang ditentukan oleh pihak sekolah, siswa diminta untuk mengembalikan raport tersebut kepada guru wali setiap kelas setelah ditandatangani oleh orang tua siswa yang telah menerimanya dan telah melihat hasil nilai siswa yang disebut dengan buku raport.

Selama raport berada di siswa, tidak semua siswa bisa menjaga raport tersebut dengan baik. Masih ada juga siswa atau orang tua siswa yang tidak peduli dan ceroboh, hal inilah yang dikhawatirkan bisa menyebabkan raport hilang, basah terkena air, sobek dan hal lainnya yang mengakibatkan kerusakan pada raport. Bukan dikalangan siswa saja, wali kelas terkadang keliru atau lupa akan tempat penyimpanan raport siswanya. Hal ini dikarenakan lemari tempat penyimpanan raport tidak tertata dengan rapi dan banyaknya raport siswa dalam satu lemari.

\section{LANDASAN TEORI \\ Definisi Sistem}

"Menurut Yakub (2012:1), "Sistem adalah suatu jaringan kerja dari prosedur-prosedur yang berhubungan, terkumpul bersama -sama untuk melakukan suatu kegiatan atau tujuan tertentu".

"Menurut Sutabri (2012:10), ebrpendapat bahwa "Suatu sistem dapat diartikan sebagai suatu kumpulan atau himpunan dari unsur, komponen, atau variabel yang terorganisir, saling berinteraksi, saling tergantung satu sama lain, dan terpadu".

\section{Definisi Sistem Informasi}

Sistem informasi terdapat beberapa pandangan menurut para ahli, antara lain sebagai berikut:

Menurut Sutarman (2014:13), "Sistem informasi adalah sistem yang dapat didefinisikan dengan mengumpulkan, memperoses, menyimpan, menganalisis, menyebarkan informasi untuk tujuan tertentu. Seperti sistem lainnya, sebuah sistem informasi terdiri atas input (data, instruksi) dan output (laporan, kalkulasi)".

Menurut Tata Sutabri (2016:46), Sistem informasi adalah suatu sistem didalam suatu organisasi yang mempertemukan kebutuhan pengolahan transaksi harian yang mendukung fungsi operasi organisasi yang bersifat manajerial dengan kegiatan strategi dari suatu organisasi untuk dapat menyediakan kepada pihak luar tertentu dengan laporan-laporan yang diperlukan.

\section{Komponen Sistem Informasi}

Komponen sistem Informasi sebagai berikut:

1. Perangkat keras (hardware): mencakup peranti-peranti fisik seperti komputer dan printer. 
2. Perangkat lunak (software) atau program: sekumpulan instruksi yang memungkinkan perangkat keras untu dapat memproses data.

3. Prosedur: sekumpulan aturan yang dipakai untuk mewujudkan pemrosesan data dan pembangkitan keluaran yang dikehendaki.

4. Orang: semua pihak yang bertanggung jawab dalam pengembangan sistem informasi, pemrosesan, dan pengggunaan keluaran sistem informasi.

5. Basis data (database): sekumpulan tabel, hubungan, dan lain-lain yang berkaitan dengan penyimpanan data.

6. Jaringan komputer dan komunikasi data: sistem penghubung yang memungkinkan sesumber (resources) dipakai secara bersama atau diakses oleh sejumlah pemakai.

\section{Definisi Penilaian}

Menurut Sudrajat dalam Yudha (2017:9), "Penilaian adalah penerapan berbagai cara dan penggunaan beragam alat penilaian untuk memperoleh informasi tentang sejauh mana hasil belajar peserta didik atau ketercapaian kompetensi peserta didik"

Menurut Nenzy Ahlung Arniyanto Putri, dkk (2014:38-43),"Penilaian adalah rujukan atau keyakinan dalam mementukan pilihan. Dapat diartikan juga sebagai patokan normative yang mempengaruhi manusia.

Menurut Yuliarto (2014:2) "Penilaian merupakan prosess pengambilan keputusan yang bersifat kualitatif sesuai dengan hasil pengukuran. Penilaian dilakukan berdasarkan kepada tujuan yang ingin dicapai".

\section{Definisi Raport}

Menurut Triyanto (2013:42). "Raport adalah laporan hasil kegiatan belajar siswa selama periode tertentu yang di implementasikan dalam bentuk nilai sekelompok mata pelajaran dengan disertai penilaian kepribadian, sikap dan tingkah laku periode yang dimasukkan adalah periode atau jenjang belajar yang berupa periode semesteran (6 bulan)".

Menurut Yudha (2017:9)."'Raport adalah buku yang berisi keterangan mengenai nilai kepandaian dan prestasi belajar murid di sekolah, yang biasanya dipakai sebagai laporan guru kepada orang tua peserta didik atau wali murid".

Menurut Mayasari (2014:52). "Raport adalah nilai dari hasil evaluasi yang dilakukan selama proses pembelajaran/nilai raport biasanya dibuat setiap semester, hasil raport tersebut dapat diketahui nilai setiap semesternya apakah mengalami peningkatan atau penurunan".

\section{LITERATURE REVIEW}

1. Dari penelitian Nursaid dkk (2015) "Pembangunan Sistem Informasi Penilaian Hasil Belajar Siswa pada SMA Negeri 2 Rembang berbasis Web". Tujuan utama penelitian ini adalah pembuatan sistem informasi yang dapat digunakan untuk penilaian hasil belajar. Penelitian ini diharapkan agar memberikan kemudahan dalam pelaksanaan kegiatan pengolahan nilai hasil belajar siswa yang dilakukan oleh Bapak/Ibu guru pengajar dan wali kelas. Metode yang digunakan dalam penelitian ini adalah observasi, wawancara, kepustakaan, analisis, perencanaan, perancangan atau desain, pembangunan, uji coba sistem serta implementasi sistem.

2. Pengembangan dan Analisis Sistem Informasi Akademik SMK Negeri 2 Depok Sleman Berbasis Web yang disusun oleh Tika Novita Sari pada tahun 2014 dari ProgramStudi Pendidikan Teknik Informatika, Universitas Yogyakarta. Penelitian ini bertujuan untuk merancang dan membuat sistem informasi akademik SMK Negeri 2 Depok Sleman berbasis web dan mengetahui kualitas perangkat lunak yang dikembangkan berdasarkan ISO 9126. Hasil dari penelitian ini adalah dikembangkannya Sistem Informasi Akademik SMK Negeri 2 Depok Sleman dengan menerapkan kurikulum 2013, menggunakan framework Codeigniter dan berdasarkan model pengembangan Waterfall. Pengujian sistem Informasi akademik dinilai dari aspek funcionally, efficiency, reliability dan usability.

3. Penelitian Paul Siregar (2015)."Sistem Informasi Pengolahan Nilai Berbasis Web Pada SMA Muhammadiyah Pacitan”. Penelitian ini bertujuan untuk membangun suatu sistem 
informasi nilai yang mempermudah pengecekan, pencatatan dan laporan data nilai siswa yang terkomputerisasi. Selain itu dengan berbasiskan web maka informasidata dapat diakses kapan saja. Hasil dari penelitian ini menghasilkan sebuah sistem pengolahan nilai yang membantu kerja guru dan wali kelas dapat mempermudah pengguna untuk melakukan proses pengolahan nilai dapat diolah secara efektif dan efesien, sehingga bisa langsung diakses serta informasi (pengumuman) dapat tersampaikan dengan baik. Adapun Metode yang digunakan dalam sistem informasi nilai siswa ini adalah dengan menggunakan PHP, HTML, dan MySQL.

4. Tinjauan studi dari penelitian Surmalinda (2016)."Rancang Bangun Sistem Informasi Nilai Siswa Pada Madrasah Ibtidaiyah Islamiyah Ngrejeng Kabupaten Bojonegoro". Penelitian ini bertujuan untuk diharapakan perekapan nilai yang ada pada Madrasah Ibtidaiyah Islamiyah Ngrejeng Kabupaten Bojonegoro yang dulunya manual dapat menjadi terkomputerisasi dan kinerja menjadi lebih efisien dan dapat juga membantu kinerja dari pihak instansi tersebut. Adapun Metode yang digunakan dalam sistem informasi nilai siswa ini adalah SDLC (System Development Life Cycle). Yang terdiri dari beberapa tahapan yaitu: identifikasi, analisis, desain, implementasi, testing, maintenance. Metodologi pengembangan yang digunakan adalah model PIECES. Dimana model PIECES merupakan urutan aktivitas yang dilakukan dalam pengembangan sistem mulai dari kinerja, ekonomi, keamanan aplikasi, efesiensi, dan pelayanan.

5. Tinjauan studi pustaka penelitian Verawati dkk (2015).“Analisis Implementasi Sistem Pengolahan Data Nilai Siswa SD Negeri 2 Katekan”. Penelitian ini bertujuan memberikan gambaran tentang hasil implementasi sistem pengolahan data nilai siswa di SD Negeri 2 katekan yang telah berjalan selama satu semester. Proses analisis dilakukan menggunakan analisis PIECES dengan membandingkan proses pengolahan nilai sebelum penerapan sistem pengolahan data nilai dengan setelah diterapkannya sistem pengolahan data nilai siswa di SD Negeri 2 Katekan .

6. Tinjauan studi pustaka penelitian Juhriah (2015)."Perancangan Sistem Informasi Hasil Penilaian Siswa di SMP Negeri 96 Jakarta Berbasis Web". Penelitian ini bertujuan untuk mempermudah bagi staff kurikulum maupun guru didalam mengelolah nilai serta bertujuan agar siswa, guru, walikelas serta user lain yang membutuhkan data nilai maupun data tentang siswa dapat diakses secara cepat dan efisien. Metode penelitian adalah metode grounded (grounded search) yaitu suatu metode penelitian berdasarkan pada fakta dan menggunakan menetapkan konsep, membuktikan teori, mengembangkan teori.

7. Tinjauan studi pustaka penelitian Anulika dkk (2014)."Design and Implementation of Result Processing System for Public Secondary Schools in Nigeria" ". Penelitian ini bertujuan untuk memudahkan pengolahan hasil nilai siswa di sekolah menengah dan memiliki beberapa kelebihan seperti pengurangan biaya pengolahan pengurangan waktu yang dihabiskan dalam menghitung hasil nilai siswa serta lebih fleksibel dan dapat dimodifikasi sesuai jenis pencatatan dan pengolahan data. Peneliti menggunakan dengan menggunakanAdobe Dreamweaver, Integrated Development Environment, untuk menciptakanGraphic User Interface dan menulis kode, MYSQL (My Structured Query Language), sebuahRelational Database Management System (RDBMS)untuk membuat tabel database dan Rumah Pribadi halamanPre-Processor (PHP), bahasa Scripting untuk berkomunikasi dengan dan memanipulasi database.

8. Tinjauan studi pustaka penelitian Takramah dkk (2015)."Student Database System for Higher Education: A Case Study at School of Public Health, University of Ghana. Tujuan utama dari penelitian ini adalah untuk menerima proses dan menghasilkan laporan akurat dan setiap pengguna dapat mengakses sistem pada internet dengan fasilitas yang disediakan dan juga dimaksudkan untuk memberikan layanan yang lebih baik kepada pengguna, konsisten, dan tepat waktu data serta informasi yang efisien dengan mengubah proses kertas ke bentuk elektronik. Sistem ini dikembangkan menggunakan teknologi seperti PHP, HTML, CSS dan MySQL. PHP, HTML dan CSS digunakan untuk 
membangun user interface dan database yang dibangun menggunakan MySQL. Sistem ini bebas dari kesalahan dan sangat efisien dan kurang memakan waktu karena perawatan yang diambil untuk mengembangkannya.

9. Tinjauan studi pustaka penelitian Llanda dkk (2016). "Assist Web-Based Grade Entry and Inquiry System”. Tujuan penelitian ini untuk memenuhi kebutuhan spesifik dari registrar, instruktur dan siswa yang bisa memempersingkat waktu mereka, usaha dan untuk meningkatkan proses dan aliran dari sistem yang ada.metodologi pengembangan perangkat lunak yang digunakan yaitu PHP, JavaScript, CSS dan bahasa HTML scripting digunakan untuk sistem awal dan MySQL DBMS digunakan untuk sistem akhir. Sistem ini dikembangkan ditemukan untuk dapat digunakan dalam hal yang efisiensi, mempengaruhi, menolong, kontrol, dan kemampuan belajar.

10. Tinjauan studi pustaka penelitian Irfan (2012). "Assessment of Student Result Information System Design in Vocational High School". Tujuan penelitian ini untuk menghasilkan perangkat lunak yang dapat mengelola data pribadi karyawan, data pribadi siswa dan data laporan hasil belajar siswa pada setiap semester dan setiap tahun dapat akses dari setiap waktu dan setiap tempat. Metode pengembangan perangkat lunak menggunakan Model Waterfall. Software pengujian dilakukan melalui pengujian kotak putih dan kotak hitam, serta alpha dan beta melalui pengujian oleh sejumlah ahli dan pengguna. Hasil rancangan akhir menggunakan PHP dan MySQL untuk mengelola data pribadi karyawan, data pribadi siswa, dan laporan siswa hasil data belajar setiap semester dan setiap data tahun.

11. Tinjauan studi pustaka penelitian Herman dkk (2013). "Grade Query System Using Mobile Devices for Students of the Juarez Autonomous University of Tabasco" ". Tujuan penelitian ini untuk mengembangkan aplikasi agar siswa dapat berkonsultasi nilai dengan perangkat mobile pada Universitas Juarez Autonomous di Tabasco. Metodologi untuk mengembangkan layanan Web menggunakan SOHDM(Hypermedia Design Methodology Based on Object-Oriented Scenario)Metodologi ini melibatkan proses siklus dalam arti bahwa, dalam tahap tertentu kembali ke salah satu tahap sebelumnya dapat dilakukan untuk memperbaiki dan disesuaikan dengan kebutuhan yang muncul.

Dari beberapa penelitian tersebut berbagai metode ada yang sama dan ada yang berbeda. Penulis menggunakan metode lain yaitu metode Backward Chaning. Dimana penelitian ini memulai dari ekspektasi apa yang diinginkan terjadi. Dan dapat menghasilkan kesimpulan yang sesuai dengan keputusan pada fakta yang ada. Serta mengunakan Unified Modelling Language (UML) sebagai modelling tools untuk menggambarkan rancangan sistem yang ada saat ini, yang digunakan Usecase Diagram., Class Diagram, Sequence Diagram, dan Actifity Diagram. Dan Database menggunakan MYSQL untuk menyimpan data-data master maupun data hasil diagnosa sistem penilalian siswa, software yang digunakan XAMPP.

\section{METODOLOGI PENELITIAN}

\section{Metode Backward Chainning}

Cara penalaran dengan memulai dari hipotesis (ekspektasi apa yang diinginkan terjadi) terlebih dahulu, dan untuk menguji kebenaran hipotesis tersebut harus dicari faktafakta yang ada dalam basis pengetahuan. penalaran dengan mencocokan fakta atau pernyataan yang dimulai dari bagian sebelah kanan (THEN dulu). Backward Chaining cocok digunakan untuk suatu aplikasi yang menghasilkan tree yang sempit dan cukup dalam, menurut Anik Andriani (2016).

2. Metode Unifed Modelling Language (UML)

sistem yang berguna untuk melakukan proses pengaturan koleksi-koleksi struktur data (database) baik yang meliputi proses pembuatan atau proses pengelolaan database.MySQLl ini bersifat open source, artinya setiap orang dimungkinkan untuk menggunakan dan memodifikasinya, sebenarnya $M y S Q L$ ini suatu produk yang berjalan pada Linux, tetapi seiring berjalannya waktu dan pengetahuan maka para pengembang 
kemudian meliris MySQL yang bisa diakses melalui Windows, menurut Ahmar Ansari Saleh (2013).

\section{Metode Penelitian}

Metode penelitian adalah suatu cara untuk memecahkan masalah ataupun cara mengembangkan ilmu pengetahuan dengan menggunakan metode ilmiah. Dalam penyusunan laporan skripsi ini penulis menggunakan beberapa teknik yang dilakukan dalam mencari dan mengumpulkan data serta mengolah informasi yang diperlukan dengan menggunakan beberapa metode sebagai berikut:

1. Metode Pengumpulan Data

\section{a. Metode Observasi}

Merupakan cara pengumpulan data yang dilakukan dengan mengamati dan mencari sumber informasi langsung dengan melalukan evaluasi terhadap masalah yang ada dan melakukan pencatatan secara sistematis terhadap unsur - unsur yang telah diteliti.

\section{b. Metode Wawancara (Interview)}

Metode pengumpulan data dilakuan melalui proses tanya jawab terhadap pihak - pihak yang terkait dapat memahami setiap permasalahaan yang terjadi. Wawancara ini untuk mendapatkan data dan keterangan secara lisan serta bertatap langsung dengan operator ataupun bagian pengecekan kualitas bahan hasil produksi didalam ruang lingkup tempat penelitian.

\section{c. Metode Studi Pustaka}

Metode Studi Pustaka, digunakan untuk mendapatkan informasi dari Studi Pustaka (Literature) yang ada. Terkait dengan penelitian yang sedang dicari penulis mengenai aplikasi sistem pakar pngecekan kualitas barang. Untuk mendapatkan perbedaan atau menghindari plagiat terhadap penelitian yang sudah dilakukan oleh peneliti lain.

2. Metode Analisa

Metode yang digunakan pada penelitian ini yaitu metode penelitian SWOT (Strength, Weakness, Opportunity, Threats), Analisa SWOT digunakan penulis sebagai alat analisis yang cukup baik, efektif, dan efesien sebagai alat yang cepat dalam menemukan kemungkinankemungkinan yang beraitan dengan perusahaan baik itu hal terbaik maupun hal terburuk.

3. Metode Perancangan

Metode perancangan merupakan tiap-tiap prosedur, teknik, dan alat bantu tertentu yang mempresentasikan sejumlah aktivitas tertentu yang digunakan oleh perancang dalam proses perancangan keseluruhan. Metode perancangan sistem berorientasi objek dengan tool menggunakan Unified Modelling Language (UML).

4. Metode Testing

Yaitu melakukan pengujian terhadap sistem informasi yang telah dibuat dengan menggunakan black box untuk unit test.

\section{HASIL DAN PEMBAHASAN}

\section{Prosedur Sistem Yang Berjalan}

Prosedur penilaian siswa sebagai berikut:

1. Guru memberikan soal ujian kepada siswa.

2. Siswa mengerjakan soal ujian.

3. Guru menilai hasil ujian.

4. Guru menuangkan hasil penilaliannya ke raport secara manual dengan alat tulis pulpen, tipe$\mathrm{x}$, dan buku raport masing-masing siswa.

5. Kepala sekolah mengecek raport siswa masing-masing, bila sudah setujui, kepala sekolah menandatangani raport tersebut.

6. Guru memberikan raport masing-masing siswa pada waktu yang ditentukan kepala wali murid. 
7. Dan pada waktu yang ditentukan juga, wali murid mengumpulkan raportnya kembali dan diberikan ke masing-masing guru kelas.

\section{Sistem Yang Berjalan Pada Use Case Diagram}

Diagram Usecase yang berjalan dalam sistem penilaian siswa di RA (Raudhatul Athfal)

Darussalam Tangerang saat ini yaitu:

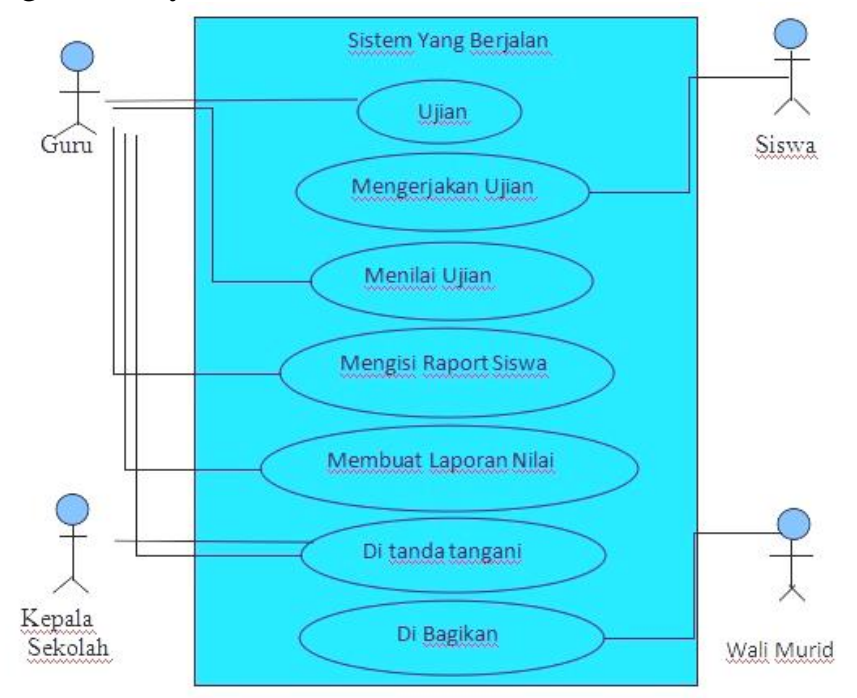

Gambar 1. Usecase Diagram sistem yang berjalan

1. 1 Sistem yang mencakup seluruh kegiatan penilaian siswa di RA (Raudhatul Athfal)Darussalam Tangerang

2. Terdapat 4 actor yang meelakukan kegiatan yaitu guru, murid, kepala sekolah dan wali murid

3. Terdapat 7 use case yang dilakukan diantara lain, guru memberikan ujian, siswa mengerjakan ujian, guru menilai hasil ujian, guru mengisi raport, guru membuat laporan nilai, ditanda tangani oleh kepala sekolah apabila kepala sekolah sudah setuju, dan dibagikan kepada wali murid.

\subsection{Sistem Yang Berjalan Pada Activity Diagram}

Activity Diagram adalah yang menggambarkan workflow (aliran kerja) atau aktivitas daru sebuah sistem atau proses bisnis. Berikut gambaran activity diagram sistem penilaian siswa RA (Raudhatul Athfal) Darussalam Kota Tangerang:

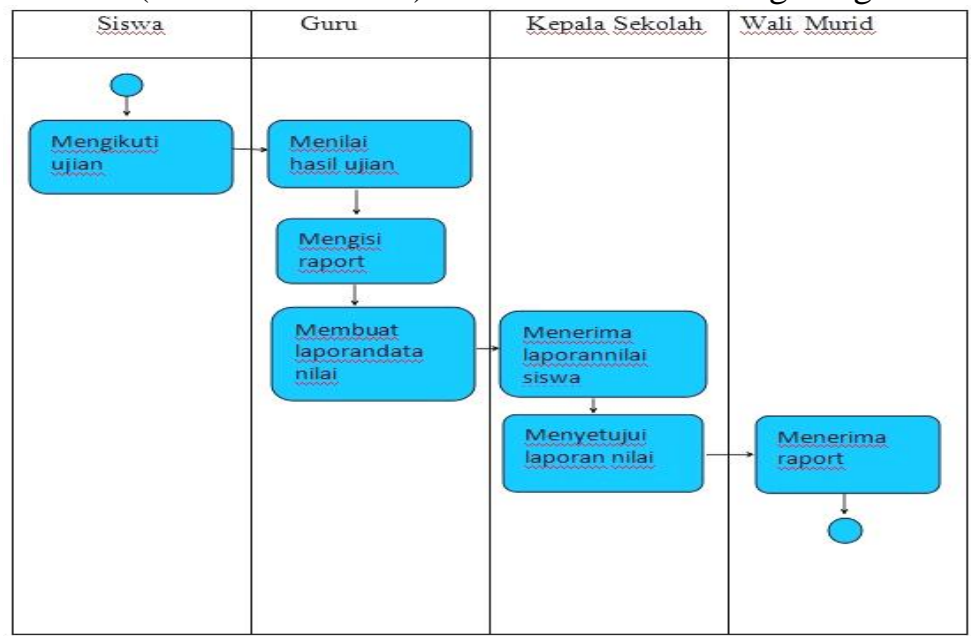

Gambar 2. Activity Diagram Penilaian Siswa 
Berdasarkan Activity Diagram yang berjalan saat ini terdapat :

1.Initial Node sebagai awal obyek.

2.7 Action dari sistem yang mencerminkan eksekusi dari suatu aksi.

3.1 Final Node sebagai obyek yang diakhiri.

4.4 Vertical Swim Line yaitu siswa, guru, kepala sekolah dan wali murid.

Sistem Yang Berjalan Pada Sequence Diagram

Sequence Diagram menjelaskan interaksi obyek yang disusun berdasarkan urutan waktu. Secara mudahnya sequence diagram adalah gambaran tahap demi tahap yang seharusnya dilakukan untuk menghasilkan sesuatu sesuai dengan Usecase diagram. Berikut gambaran sequence diagram sistem penilaian siswa pada RA (Raudhatul Athfal) Darussalam Kota Tangerang:

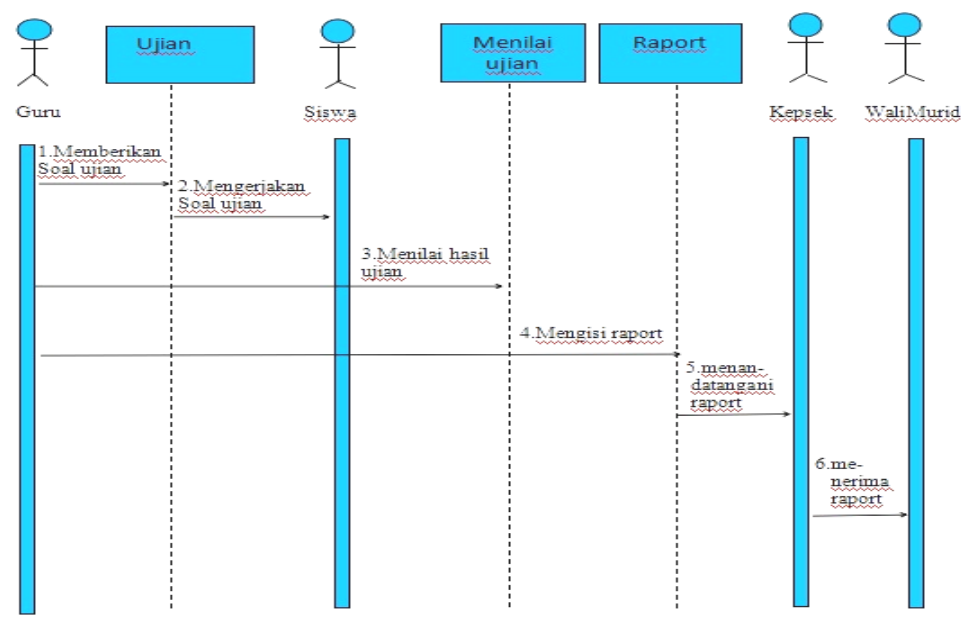

Gambar 3. Sequence Diagram

Berdasarkan Sequence Diagram yang berjalan saat ini terdapat:

1. 5 Lifeline yaitu Ujian, Menilai Ujian, Raport.

2. 4 Actor yang melakukan kegiatan yaitu Guru, Siswa, Kepala sekolah, Wali murid.

3. 6 Message spesifikasi yang terjadi dari komunikasi antar objek yang memuat informasiinformasi tentang aktifitas yang terjadi.

\section{RANCANGAN TAMPILAN SISTEM}

\section{Tampilan Halam Login}

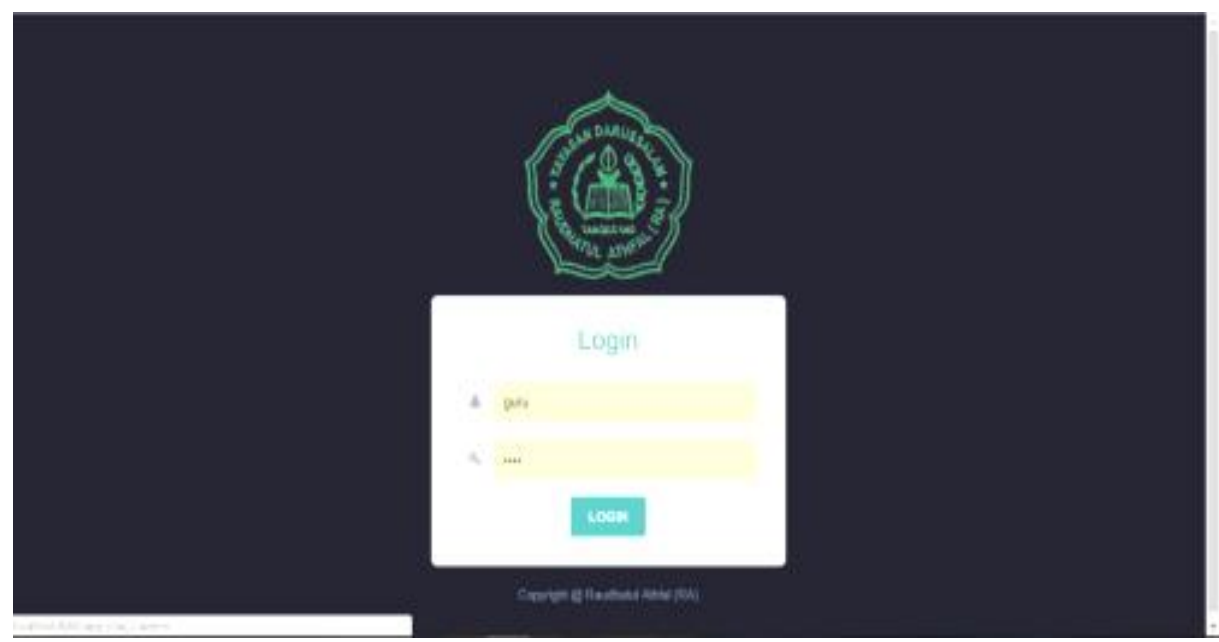

Gambar 4. Tampilan Halaman Login 
Tampilan ini merupakan tampilan awal pada sistem, untuk dapat masuk kedalam sistem harus melakukan login dengan memasukan username dan password dengan benar.

\section{Tampilan Halaman Menu Dashboard User}

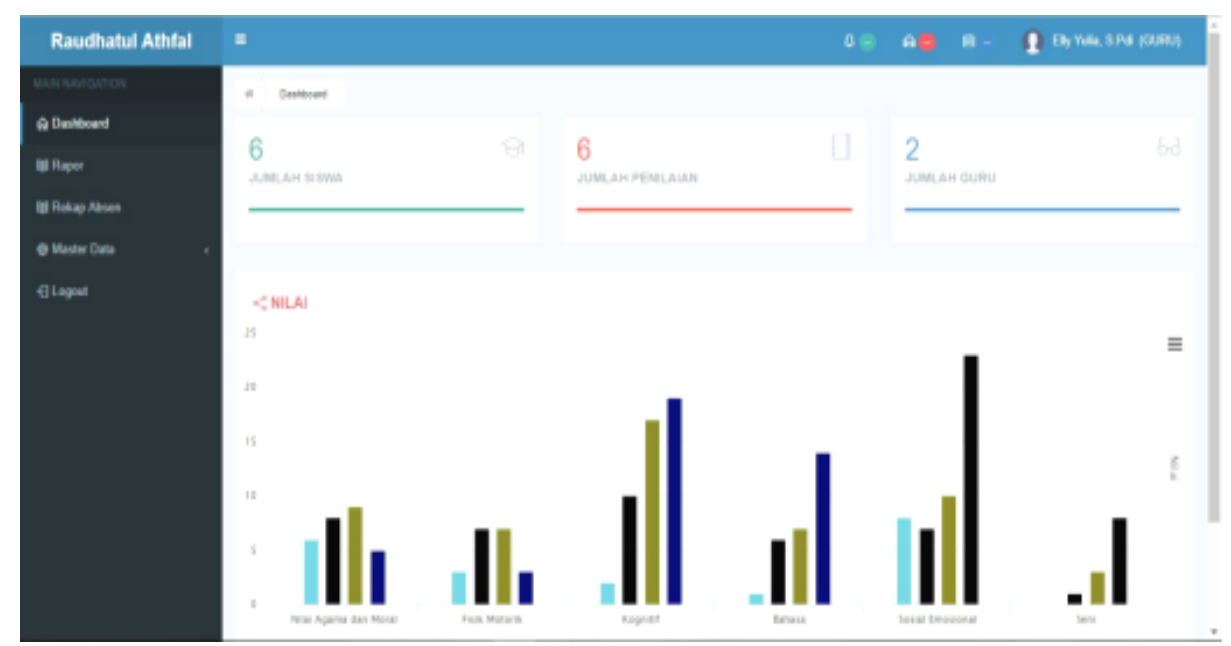

Gambar 5. Tampilan Halaman Menu Dashboard User

Tampilan diatas merupakan halaman yang menampilkan beberapa kategori, yaitu raport, rekap absen, master data, logout.

\section{Tampilan Halaman Data Siswa}

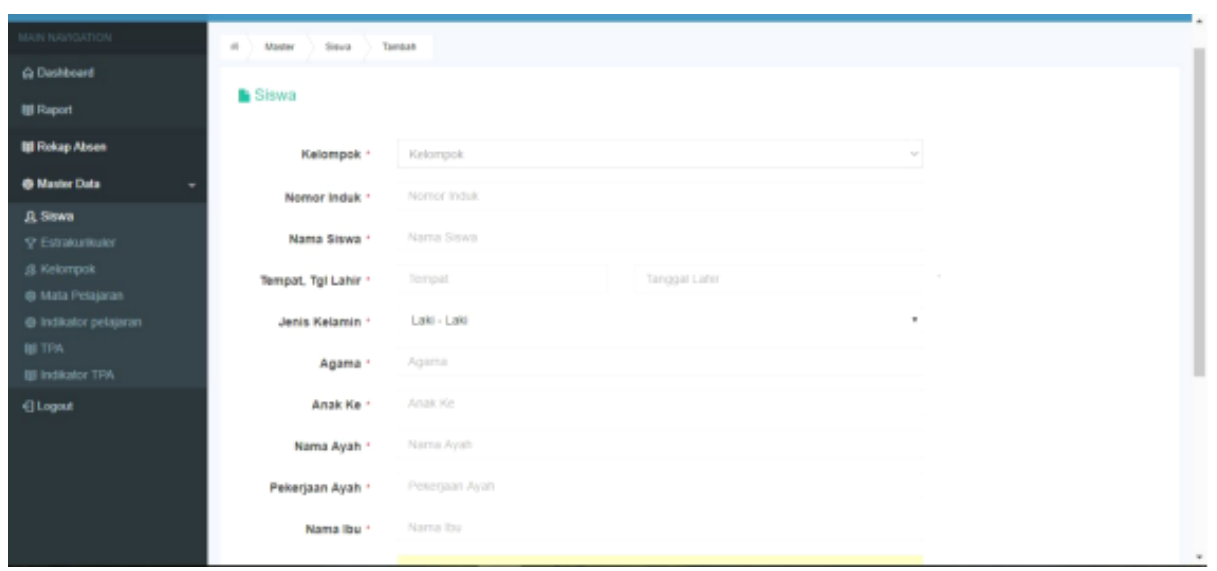

Gambar 6. Tampilan Isi Data Siswa

Tampilan diatas merupakan isi data siswa yang harus diisi, guna menambahkan dats siswa yang akan dinilai raportnya. 


\section{Tampilan Halaman Raport}

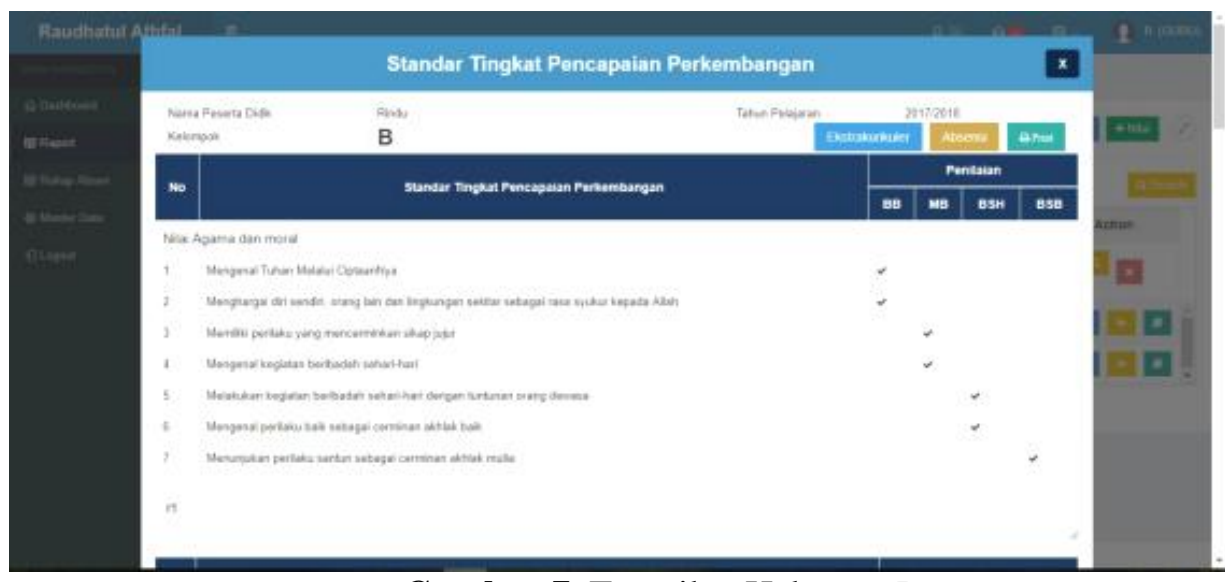

Gambar 7. Tampilan Halaman Raport

Tampilan diatas adalah halaman nilai raport yang harus diisi oleh guru sesuai penilaian dari masing-masing siswa, dan terdapat beberapa pelajaran didalamnya.

\section{Tampilan Halaman Rekap Absen Siswa}

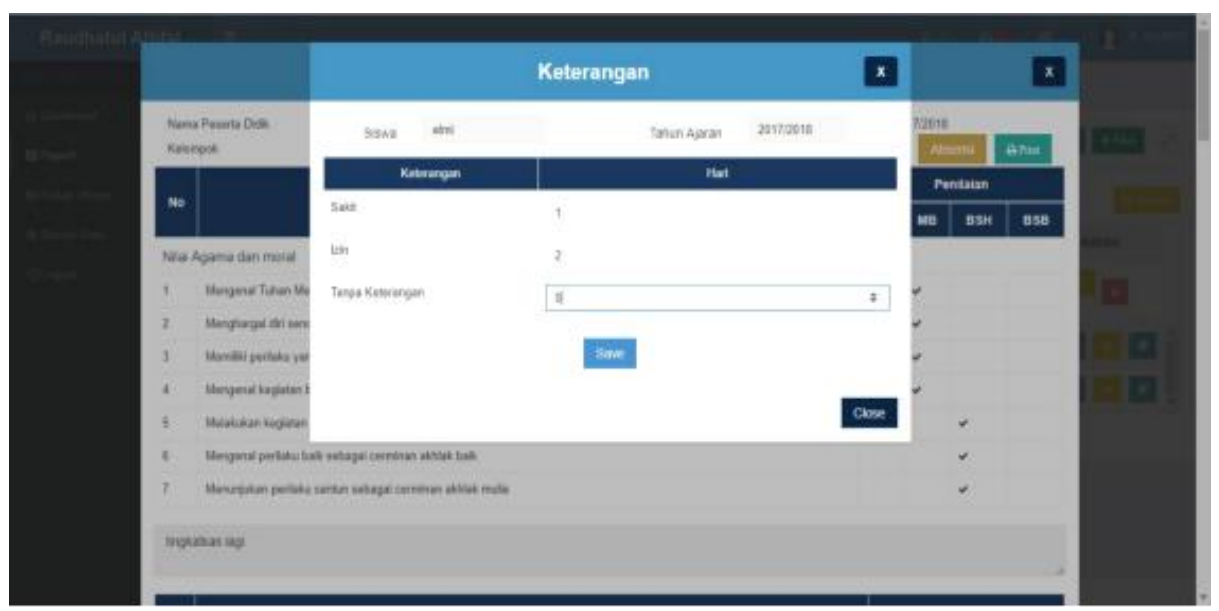

Gambar 8. Tampilan Halaman Rekap Absen Siswa

Tampilan diatas merupakan inputan absen dari salah satu siswa yang harus diisi sesuai kehadiran siswa selama satu semester.

\section{KESIMPULAN}

1. Sistem penilaian raport yang berjalan saat ini di RA (Raudhatul Athfal) Darussalam Tangerang masih manual. Mekanisme kerjanya adalah menerima berkas 35 siswa dari setiap guru mata pelajaran setelah itu dicatat dalam buku yang disebut dengan raport. Setelah penyalinan tersebut raport disimpan dan dibagikan kepada setiap wali murid pada waktu penyerahan raport berlangsung. Dalam jangka waktu yang ditentukan oleh pihak sekolah, siswa diminta untuk mengembalikan raport tersebut kepada guru kelas masingmasing.

2. Kendala dalam penilaian raport yang berjalan saat ini di RA (Raudhatul Athfal) Darussalam Tangerang adalah adanya 35 siswa dan masing-masing mempunyai nilai yang berbeda-beda, sehingga membutuhkan waktu yang sangat lama dalam pengerjaannya. 
Terkadang raport tersebut kotor terkena makanan, atau sobek karna kena air, dan jika tulisan guru salah enggunakan tipe-x yang membuat raport terlihat tidak rapih.

3. Sistem Informasi dirancang menggunakan metode object oriented programming dengan menggunakan tools UML (Unified Modeling Language), bahasa pemrograman PHP dan database MySQL. Sistem ini memudahkan guru dalam laporan penilaian masing-masing siswa, memudahkan orang tua murid melihat nilai anaknya.

\section{DAFTAR PUSTAKA}

[1] Juhrian, Een. 2015. "Perancangan Sistem Informasi Hasil Penilaian Siswa di Smp Negeri 96 Jakarta Berbasis Web". Jakarta: Journal Lppmunindra Universitas Indraprasta PGRI Tahun 2015.

[2] Rahman Taufiq. 2015. Sistem Informasi Manajemen. Yogyakarta: Graha Ilmu.

[3] PAUD JATENG. 2015. "Cara Penilaian Harian PAUD K-13”. Diakses pada link http://www.paud.id/2015/11/strategi-pelaksanaan-penilaian-harian-paud.html

[4] Danny Pratama,dkk. 2017. "Elisitasi”. Diakses pada link https://widuri.raharja.info/index.php/Elisitasi

[5] Arief. 2017. "Nilai Informasi". Diakses pada link http://informatika.web.id/nilai-informasi.htm

[6] Rusdiana. A, Irfan. Moch. 2014. "Sistem Informasi Manajemen”. Bandung : Pustaka Setia.

[7] Mulyani, Sri. 2016. "Metode Analisis dan Perancangan Sistem". Bandung. AbdiSistematika. ISBN : 978-979-199096-2-2.

[8] Paul Siregar.2015. "Sistem Informasi Pengolahan Data Nilai Siswa Berbasis Web Pada SMA Muhammadiyah Pacitan". Diakses pada link http://pendidikansrg.blogspot.com/2015/10/sistem-informasi-pengolahan-data-nilai.html?=1 